\title{
Botanické putování jižním Vietnamem za současníky Cyrila a Metoděje
}

\author{
Otakar Š́da ${ }^{1}$, Romana Rybková ${ }^{2}$ \& Vlastik Rybka \\ ${ }^{1}$ Národní muzeum, botanické oddělení, Cirkusová 1740, 19300 Praha 9 - Horní Počernice; \\ otasida@seznam.cz \\ ${ }^{2}$ Botanická zahrada hl. m. Prahy, Trojská 800/196, 17100 Praha 7 - Troja
}

Šída O., Rybková R. \& Rybka V., 2020: Botanické putování jižním Vietnamem za současníky Cyrila a Metoděje. - Journal of the National Museum (Prague), Natural History Series 189: 181-192.

Řečeno suchým vědeckým jazykem, Vietnam leží v Indočínské květenné oblasti. Přeloženo to znamená, že jeho květena se podobá ostatním oblastem Zadní Indie a jedná se o květenu s výjimkou nejzazšího severu tropickou, která je ovlivněna více či méně výrazným střídáním období sucha a monzunových deštůu. Přesto má ale vietnamská flóra svoje specifika. Území Vietnamu je výrazně protáhlé v severojižním směru, zatímco v nejužším místě svého území je laosko-vietnamská hranice vzdálená od pobřeží pouhých 40 km, od severu k jihu Vietnam měří více jak $1600 \mathrm{~km}$ a rozprostírá se přes 15 šíŕkových zeměpisných stupňů. Podél severní a západní hranice se táhnou horské systémy dosahující nezřídka výšek přes 2000 m a vrcholících na severozápadě nejvyšším bodem celé Indočíny - $3143 \mathrm{~m}$ vysokou horou Fan Siobr. Pan. Tyto výrazné rozdíly v zeměpisné šířce i velká výšková členitost značně ovlivňují klima - a tím pádem samozřejmě i složení flóry. Zatímco jih území v okolí Saigonu má téměř

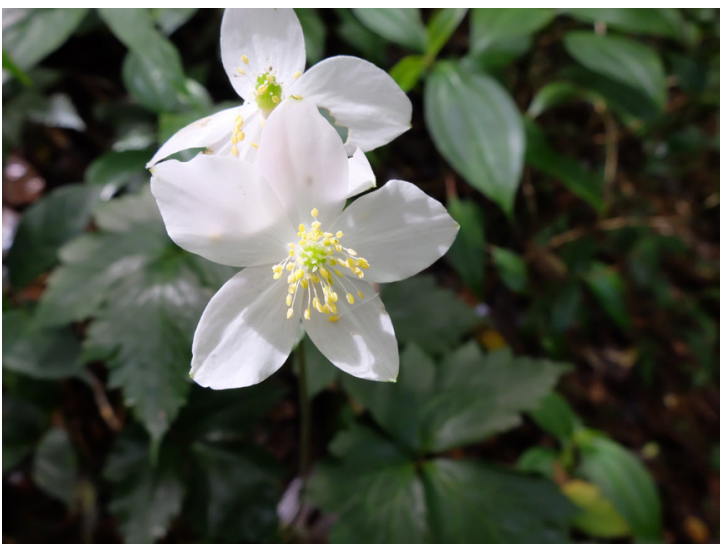

Obr. 1. Anemone sumatrana (Ranunculaceae). rovníkové klima s horkou zimou a poměrně vyrovnaným přísunem srážek během roku, oblasti na severu mají zpravidla výrazné monzunové klima s obdobím sucha, v horských polohách nejsevernějšího Vietnamu bývá i období vegetačního klidu způsobené nízkou teplotou (vrcholové polohy Fan Si Panu vzácně znají dokonce sníh).

Severojižně orientované horské systémy fungují na jedné straně jako migrační koridory, usnadňující širréení rostlin, na straně druhé usnadňují přežití specifických endemických prvků 


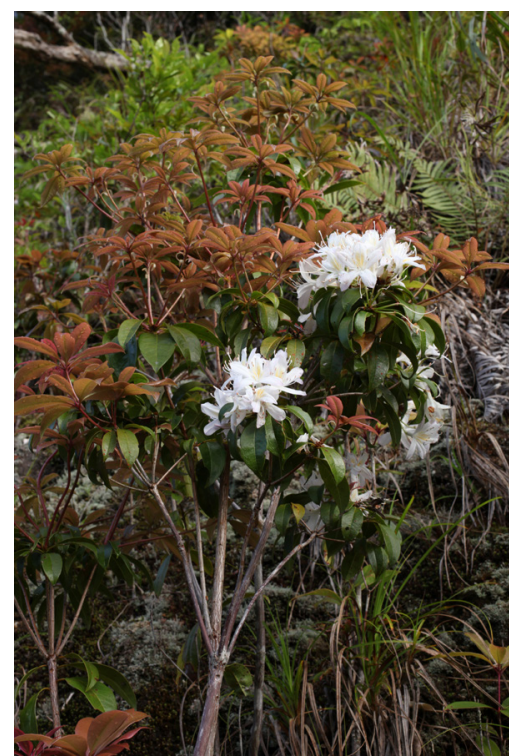

Obr. 2. Rhododendron moulmainense (Ericaceae). tzv. „na místě“, kdy během měnícího se klimatu těmto rostlinám stačí přesouvat se podle výškového gradientu na krátké vzdálenosti. Ve flóře Vietnamu nenalezneme pouze prvky evolučně spjaté s územím vlastní Zadní Indie, ale proniká sem i řada temperátních prvků od severu. Podobná vazba existuje i na rovníkové oblasti Malajského poloostrova a Bornea. Dnes jsou tato území oddělena vodami Thajského zálivu, ale ještě před 15000 lety během poslední doby ledové, kdy byla hladina světových oceánů výrazně níže než dnes, byl tento mělký šelf nad hladinou a rostliny se tudy mohly radostně šířit. Tyto historické důvody, stejně tak jako výrazně diverzifikované klima a reliéf jsou zodpovědné za velice bohatou flóru, ve které se prolínají prvky čistě tropické s těmi pocházejícími z mírného pásu. Můžeme přijít do lesa, ve kterém na břehu drobného potoka roste rovníková Pentaphragma, archaické kapradí z rodu Marattia nebo Phylagathis z čeledi Melastomataceae se zástupci indočínských rodů Argostemma a Globba, to vše rámováno velkokvětými sasankami, nad nimi se po keřovitém temperátním pěnišníku (Rhododendron) pne opět rovníková láčkovka (Nepenthes) a ve stromovém patře nad nimi roste kromě jiného i dub, borovice, javor, anebo bříza. Ve Flóře Vietnamu je evidováno přes 12000 druhů cévnatých rostlin, podle v posledních letech bouřlivě odhalované diverzity v některých skupinách jich zde ale ve skutečnosti bude výrazně více - patrně až ke 20 tisícům. A s tím se pojí jedna závažná neradostná skutečnost. Vietnamská flóra (ale platí to stejně i pro ostatní oblasti tropické jihovýchodní Asie) ještě ani zdaleka není kompletně probádaná. Současná plocha přírodních ekosystémů jsou pouhé zlomky jejich dřívější rozlohy a i ty pod antropickým tlakem dále rychle mizí. Je spíše jisté, než pravděpodobné, že velké množství rostlinných druhů zmizí ještě dříve, než vůbec budou vědecky popsány, natož abychom se dozvěděli cokoli o jejich biologii, ekologii, nebo obsahových látkách. Pohříchu se bude nejčastěji jednat o ty druhy vzácné, často endemické, které by z hlediska ochrany př́rody byly ty nejcennější. Široce rozšířené běžné druhy byly již popsány v (často dávné) minulosti, při současném t a x o n o m i c kém výzkumu $\mathrm{v}$ podstatě na poslední chvíli vyzobáváme ty vzácnosti, které dosud nikdo nezachytil, a je jejich smutným osudem, že přidělené vědecké jméno je často tím jediným epitafem, který lze za pár let vytesat na jejich pomyslný náhrobek.

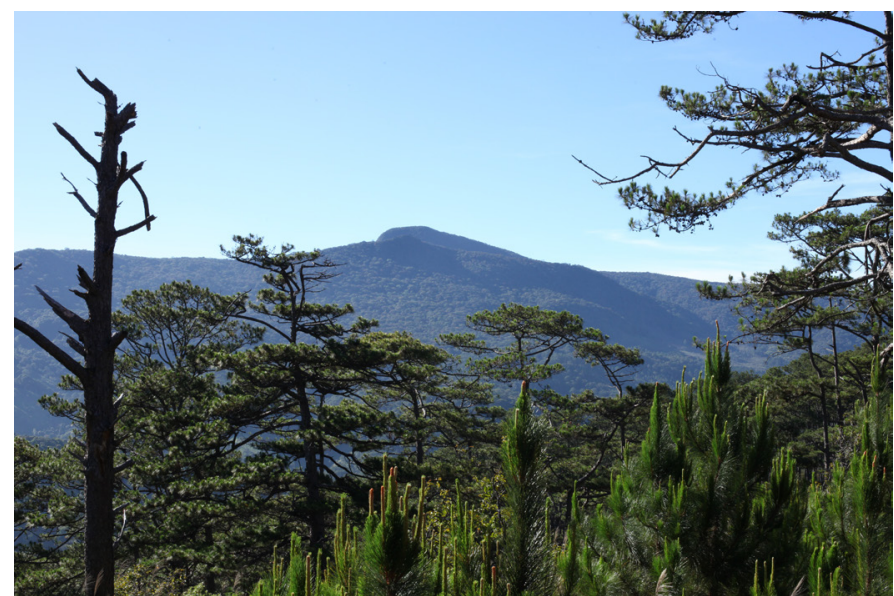

Obr. 3. Nejvyšší vrchol národního parku Bidoup (2287 m). 


\section{Ze Saigonu do jižních Annamitů}

$\mathrm{Na}$ základě dlouhodobé spolupráce mezi botanickým oddělením Národního muzea a Botanickou zahradou hlavního města Prahy a díky memorandu, které tato zahrada uzavřela s Institutem tropické biologie v Nha-Trangu, jsme na jaře 2017 uspořádali společnou expedici do území jižních Annamitů. Oblast představuje nejzazší jižní výběžky horských systémů, které probíhají celou jihovýchodní Asií od Himálaje až po jižní Vietnam a Malajský poloostrov. Tento nejvýchodněji položený hřeben, který se táhne více méně po celé délce hranice Vietnamu a Laosu a na vietnamském území podél pobřeží pokračuje téměř až nadohled k Ho Či Minovu Městu, propojuje v podstatě plně tropický jižní Vietnam se subtropy jižní Číny, které zase plynule navazují na temperátní vyšší polohy východu Tibetské plošiny. Naším cílem bylo území národního parku Bidoup-Núi Bà, který spolu se sousedními národními parky Chư Yang Sin, Phước Bình a prírodní rezervací Hòn Bà chrání jádro tohoto horského systému.

Hned po prríletu do Ho Či Minova Města nás vyzvedla dodávka z naší partnerské organizace $\mathrm{v}$ Nha-Trangu, s kterou jsme ve velmi brzkých ranních hodinách vyrazili k severovýchodu. Ho Či Minovo Město je standardní tropická megapole svojí populací srovnatelná s celou Českou republikou, a protože in-

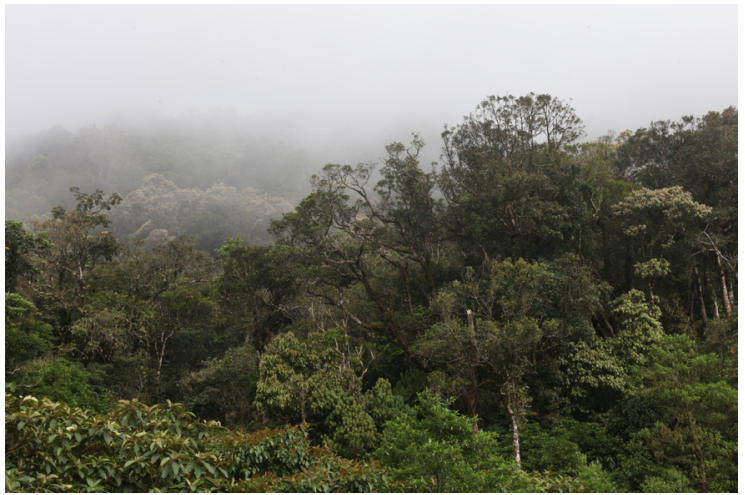

Obr. 4. Horský stálezelený les v sedle Hon Giao. frastruktura pokulhává za jejím bouřlivým rozvojem, lze v ní denní dopravu charakterizovat jako jednu obrovskou zácpu od severu k jihu a od východu k západu. Více méně jediná možnost, jak město opustit v rozumném časovém horizontu, je vyrazit na cestu v půl páté ráno. Tak jsme i učinili a po celodenní cestě, probíhající částečně po pobřeží Jihočínského moře nejsuššími oblastmi Vietnamu, které připomínají spíše africkou savanu, než vlhké asijské tropy, jsme dorazili do Nha-Trangu. Zde nás čekali naši ruští kolegové, manželé Kuznetsovovi, kteří nám zajistili ubytování př́imo v institutu. Ještě téhož večera jsme podnikli válečnou poradu, doladili poslední detaily ohledně potřebného materiálu a plánu na příští dny a druhý den ráno vyrazili k západu do hor. Silnice Nha-Trang - Da-Lat přes sedlo Hon Giao byla vybudována teprve zhruba před dvaceti lety. Do té doby byla oblast Bidoupu téměř nedostupná a př́ístup do ní byl otázkou pětidenního pěšího pochodu horským pralesem. Nyní už zde stojí nově vybudovaný turistický resort, ve kterém jsme se ubytovali i my. Svou budovu tu má i správa národního parku, dokonce tu provozuje i malé informační centrum o místní přírodě. V národním parku jsme se pohybovali v různých typech montánního lesa v nadmořských výškách zhruba mezi 1300 a 2000 m n. m., na území sice nevelkém, ale vysoce rozmanitém. Při pohledu do klimatologického atlasu zjistíme, že v podstatě celé území Vietnamu leží v monzunové oblasti tropického klimatického pásu, čili bychom zde mohli očekávat stejné klima jako ve většině jižní Asie od Pákistánu po Indočínu. Toto klima ovlivňuje stř́ídání letního a zimního monzunu, kdy letní vane od jihozápadu a přináší s vlhkým a teplým vzduchem od moře srážky, zatímco zimní vane od severovýchodu a přináší suchý a chladný vzduch z nitra kontinentu. Proto zpravidla existují tři dobře odlišená roční období: chladné, v období našich zimních měsíců (chladné znamená, že teploty obvykle nepřekračují $30^{\circ} \mathrm{C}$, a tudíž se dá venku docela dobře fungovat), horké, v období našeho jara až časného léta (horké znamená, že teploty naopak zpravidla překračují $40^{\circ} \mathrm{C}$, a venku se tudíž fungovat nedá) a vlhké, v období našeho pozdního jara, 


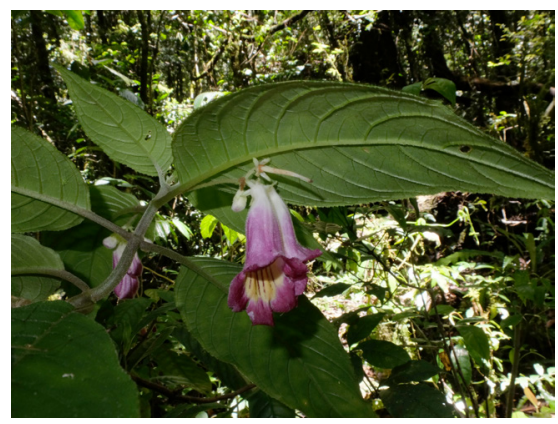

Obr. 5. Raphiocarpus ewrardii (Gesneriaceae).

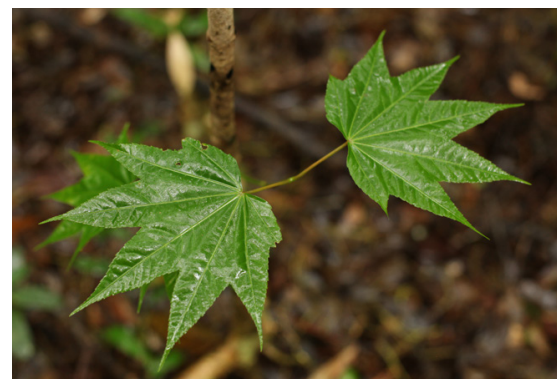

Obr. 7. Acer campbellii (Aceraceae). velké rozdíly jak v teplotách, tak v ročních srážkových úhrnech a jejich rozložení během roku. Značně rozrůzněný terén zároveň způsobuje, že se klimaticky velmi odlišné oblasti střídají na krátkých vzdálenostech, často i pouhých několika km.

Přestože tropický les na první pohled z dálky vypadá jako jednolitý uniformní zelený baldachýn, ve skutečnosti se jedná o velmi rozmanitá prostředí a složení i fyziognomie jednotlivých vegetačních typů se značně mění. Flóra jednotlivých typů lesa je natolik rozdílná, že v nich najdeme jen málo společných druhů. Pojd'me si nyní jednotlivé typy lesa představit.

Představy, jak má tropický deštný les vypadat, nejlépe splní lesy v okolí sedla Hon-Giao a na východních svazích tohoto hřebene, na plochách, které mají dostatek srážek v průběhu celého roku. V našem případě se jedná o horský stálezelený les, který oproti klasické nížinné variantě má méně pater, stále se ale jedná o porosty s plně zapojeným vysokým stromovým patrem tvořeným velkým množstvím druhů dřevin a jedním až dvěma patry nižších stromů a keřů pod nimi. Ve stromovém patře nalezneme jak tropické rody, jako je rod Exbucklandia z čeledi Hammamelidaceae nebo Camellia z čeledi Theaceae, tak i temperátní prvky jako je Castanopsis, dub Quercus macrophylla, javor Acer campbellii, či borovice Pinus krempfii. Bylinné patro je bohaté, vyskytuje se zde množství kapradin, rostlin z příbuzenstva afrických fialek - zástupců čeledi Gesneriaceae (např. mohutný, až

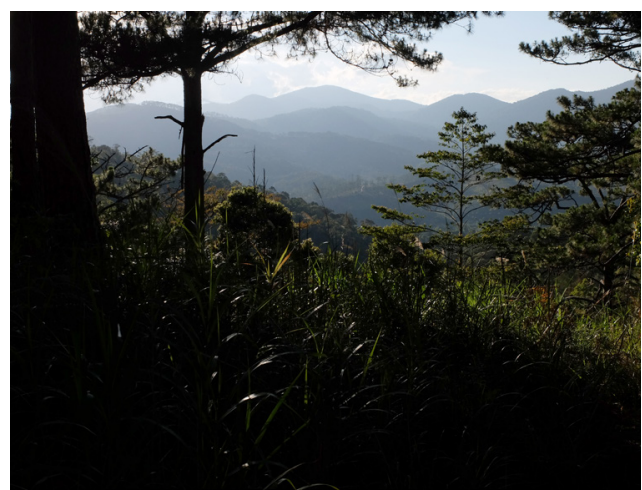

Obr. 8. Bory s Pinus dalatensis (Pinaceae) v nižších partiích západních svahů hory Bidoup. 


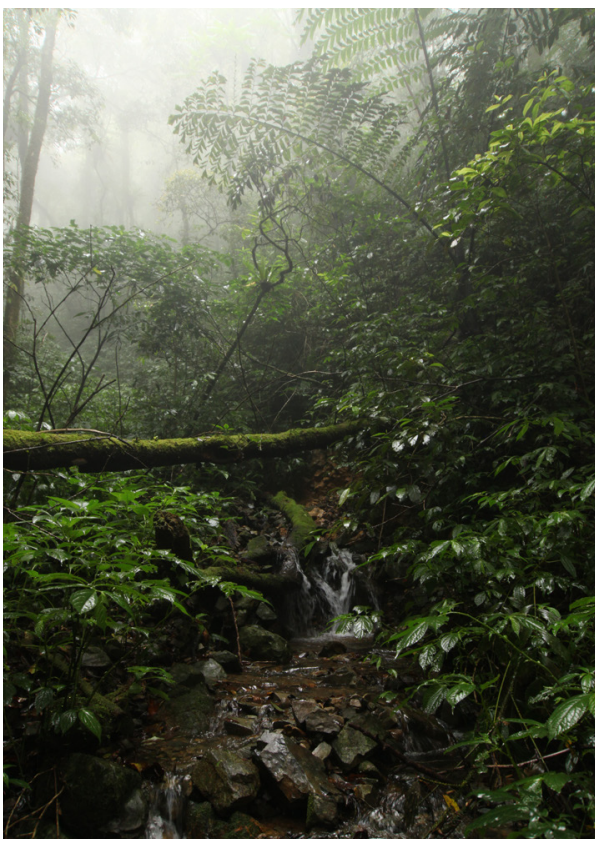

Obr. 9. Nejvlhčí facie horského deštného lesa se vyskytují na východních svazích hlavního hřebene ve stržích drobných vodotečí. $V$ pozadí palma rodu Caryota (Palmae).

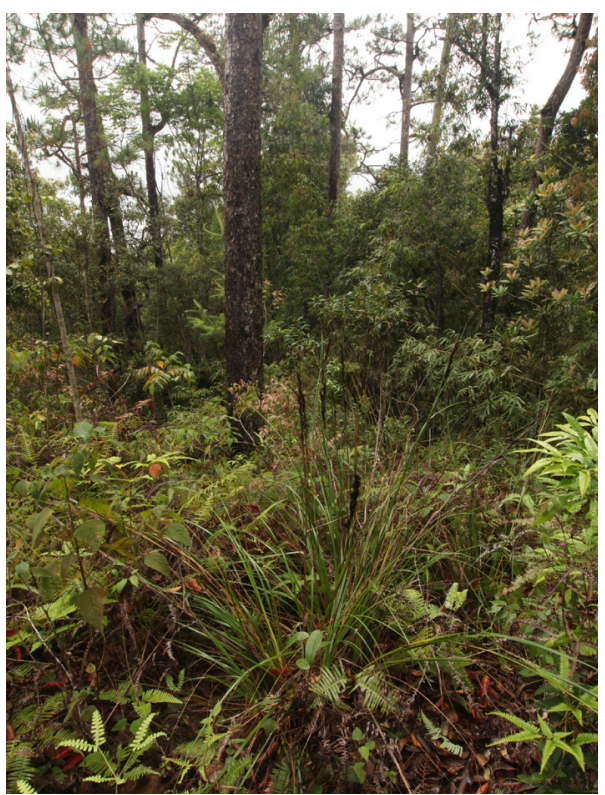

Obr. 10. Světlý poloopadavý les na hřbetech ve srážkovém stínu hlavního hřebene. $V$ popředí trs rodu Gahnia (Cyperaceae) a kapradiny z rodu Dicranopteris (Gleicheniaceae).

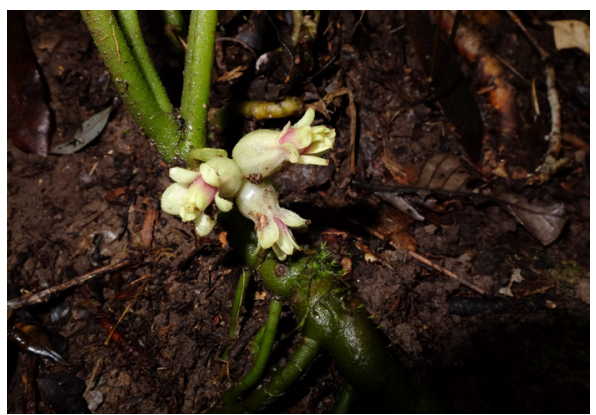

Obr. 11. Pentaphragma honbaense

(Pentaphragmataceae).

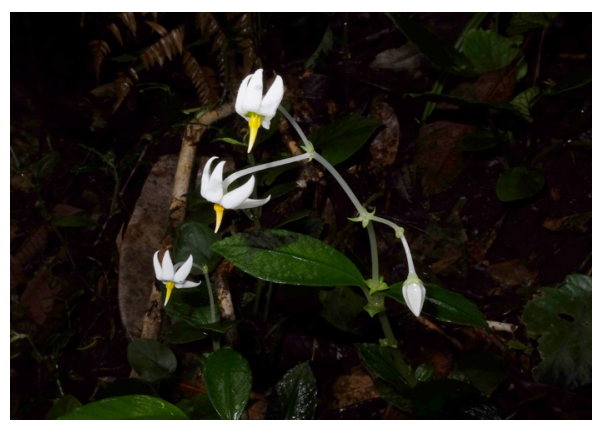

Obr. 12. Argostema sp. (Rubiaceae).

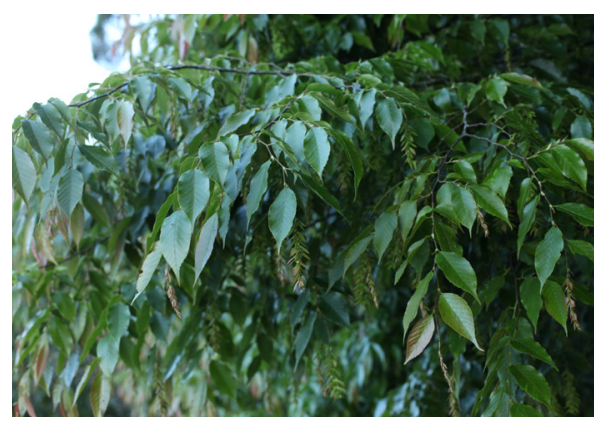

Obr. 13. Carpinus londoniana (Betulaceae) roste v podobných místech jako naše olše - podél břehů horských řek.

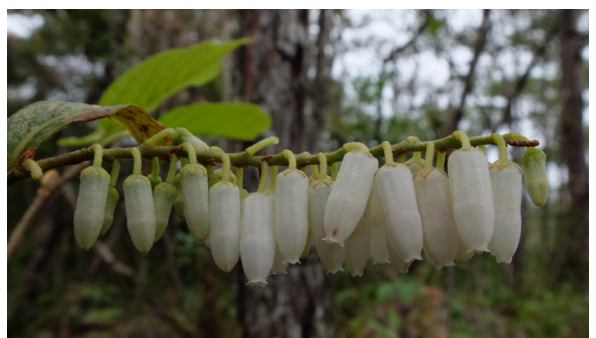

Obr. 14. Lyonia ovalifolia (Ericaceae). 


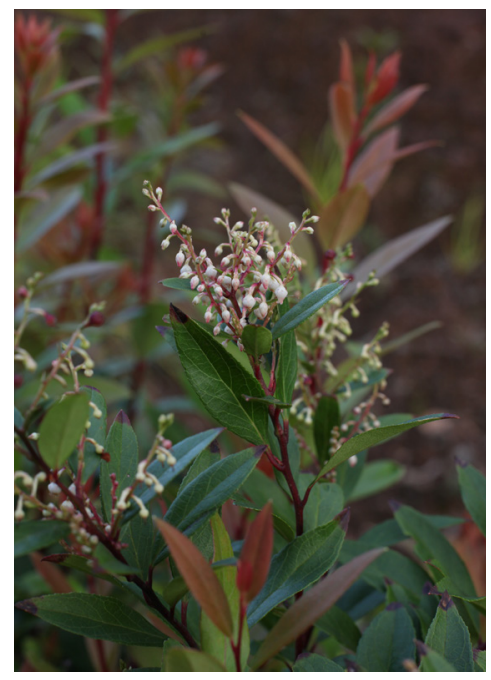

Obr. 15. Gaultheria aff. sleumeri (Ericaceae).

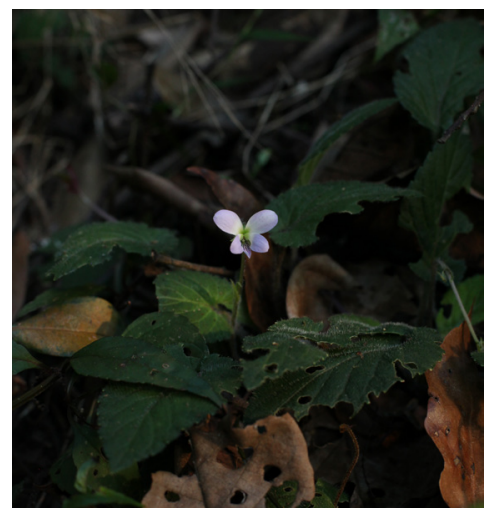

Obr. 16. Viola dalatensis (Violaceae).

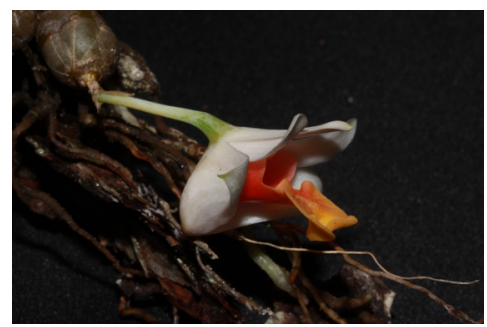

Obr. 17. Dendrobium bellatulum (Orchidaceae).
1,5 m vysoký Raphiocarpus ewrardii), zázvorů, pozemních orchidejí nebo bylinných zástupců čeledi Melastomataceae z rodu Phyllagathis.

Nejvlhčí variantu tohoto lesa nalezneme v zaříznutých roklinách horských bystřin. Zde se vlhkost vzduchu neustále udržuje velmi vysoko a z hlediska mikroklimatu se jedná o nejstabilnější prostředí. Př́mo na březích potoků rostou drobní zástupci rodu Argostemma (Rubiaceae) s květy ve tvaru hvězdiček, anebo z evolučního hlediska zajímavá Pentaphragma honbaense. Čeled' Pentaphragmataceae zahrnující jediný rod je vázána svým rozšířením na JV Asii a, ač na to na první pohled nevypadá, jedná se o příbuznou hvězdnicovitých, čili těch našich sedmikrásek, pampelišek a aster. Ve stromovém patře se občas vyskytuje jehličnan Nageia wallichii (Podocarpaceae) s plochými širokými kopinatými jehlicemi, které připomínají cokoli jiného, jen ne naši borovici nebo smrk. Roztroušeně se vyskytují stromové kapradiny rodu Cyathea anebo palmy z rodu Caryota (viz obr. 9).

Dále od hlavního hřebene, kde se celkové úhrny srážek snižují, vypadá les dosti odlišně. V nižších partiích masivu Bidoup, zhruba 20 km k jihovýchodu, narazíme na les, který jako by z oka vypadl karpatskému boru, i s tou hasivkou orličí. Jen borovice nejsou lesní, ale patř́i druhu Pinus dalatensis, endemickému druhu borovice vyskytujícím se pouze v horách nejjižnějších Annamitů. Tyto sušší oblasti jsou pod značným antropickým tlakem, at' již se jedná o lesnické využití, kdy jsou přirozené porosty nahrazovány borovými monokulturami často nepůvodních druhů borovic, anebo jsou tyto plochy převáděny na plantáže kávovníku. Vietnamská káva je vynikající a plochy těchto plantáží, z hlediska ochrany přírodních biotopů bohužel, se rozšiřují prímo raketovým tempem.

Se zvláštním typem podobně suchého lesa se potkáváme $\mathrm{v}$ územích ve srážkovém stínu kousek za hlavním hřebenem ve vrcholových partiích horských hřbetů a jejich vrcholů v nadmořských výškách kolem $1500 \mathrm{~m}$. Tyto polohy se vyznačují relativně mělkou půdou a zdejší lesní porosty bývají nižší, zpravidla jedno- až dvoupatrové, hodně světlé a rozvolněné. $V$ určitém období roku je zde výrazné období sucha. Část dřevin proto během tohoto období shazuje listy, ostatní alespoň přestávají růst. Ve velkém se zde vyskytují rostliny, které s oblibou osídlují i pionýrská stanoviště čerstvě obnažených půdních odkryvů podél cest, silnic a podobně. Typické jsou kapradiny rodu Dicranopteris, plavuň Lepidotis cernua, libavky (Gaultheria aff. sleumeri), rododendrony, anebo trsnaté ostřicovité z rodů Carex a Gahnia. Dřeviny ve světlých a rozvolněných porostech porůstá množství epifytů, a to nejen v korunách, ale i na spodních čás- 

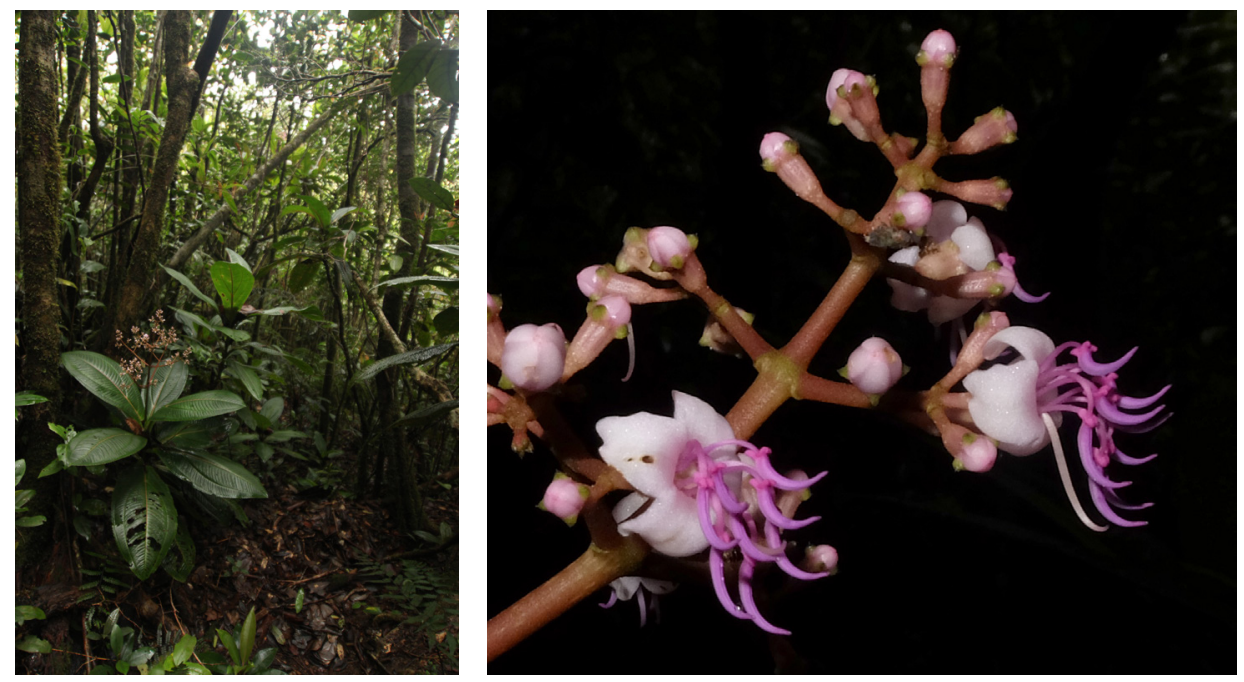

Obr. 18, 19. Marrumia muscosa (Melastomataceae).

tech kmenů. Kromě všudypř́tomných mechů a lišejníků jsou hojně zastoupeny i suchomilné kapradiny, např. Davallia repens, a samozřejmě orchideje. Tato oblast patří k orchidejové pokladnici Vietnamu, nám se poštěstilo zastihnout v květu Dendrobium bellatulum, které patří mezi pěstitelsky nejoblíbenější druhy, a zástupce jednoho z druhově nejbohatších rodů cévnatých rostlin vůbec, rodu Bulbophyllum. Bohužel v přírodě je ohrožuje nejen intenzivní sběr na prodej, ale i ztráta stanovišt', stejně jako mnohé další vietnamské orchideje. Čeled' vřesovcovitých reprezentuje epifytický keř́k Lyonia ovatifolia.

Poslední vegetační typ potkáváme ve vyšších partiích hlavního hřebene v okolí sedla Hon Giao, které jsou hojně zásobeny vodou v průběhu celého roku. Stejně jako u předcházejících společenstev i zde jsou rostliny limitovány mělkou vrstvou půdy, nemusejí ale řešit nedostatek vody, prší zde více méně pravidelně během celého roku. Porosty jsou proto taktéž nízké a s málo patry, jsou ale více zapojené a zastoupení epifytů je větší. V podstatě veškerá plocha kmenů a větví je pokrytá koberci mechů a drobných kapradin. Ve vrcholových partiích porosty přecházejí v husté, jenom 2-4 m vysoké křoviny. Součástí keřového patra byla $\mathrm{v}$ těchto lesích mohutná Marrumia muscosa z čeledi Melastomataceae s opravdu obřími listy o délce až $60 \mathrm{~cm}$. $\mathrm{V}$ podrostu jsme dále nalezli prapodivnou nezelenou př́ibuznou našich hruštiček - Monotropastrum humile. Rostlina zcela postrádá chlorofyl a je svoji výživou plně odkázaná na symbiotické houby - jde o rostlinu s takzvanou mykoheterotrofní výživou. I když s tou symbiózou je to $\mathrm{v}$ tomto př́padě poněkud diskutabilní. Rostlina, která v průběhu evoluce zcela ztratila jakýkoli chlorofyl, houbě žádný prospěch nepřináší a ani přinášet nemůže. Takže, přesněji řečeno, na níparazituje.

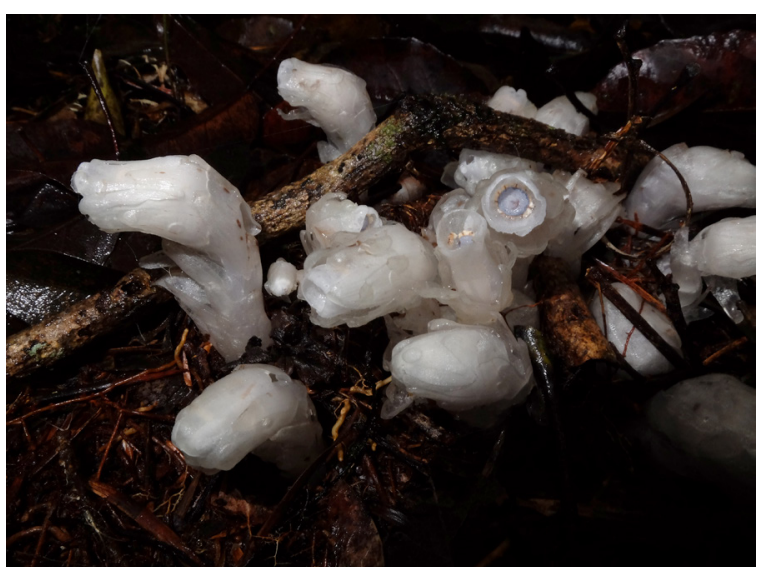

Obr. 20. Monotropastrum humile (Ericaceae). 


\section{Palmy lesů, vod a strání}

Řekne-li se palma, většina lidí si představí kokosové na pobřeží. Palmový svět je ale výrazně pestřejší. Čeled' Arecaceae obsahuje necelých 200 rodů a 2800 druhů. Nejbohatší oblasti jsou tropy Ameriky, Sundské ostrovy a Madagaskar, ale i ve Vietnamu se jich najde dost.

Palmy obývají prostředí značně rozdílná. Od zmíněných kokosů na mořském pobřeží, nyp (Nypa fruticans) ve sladkovodních i brakických bažinách na dolním toku Mekongu přes tmavý podrost nížinného lesa až po křovité porosty $\mathrm{v}$ nejvyšších polohách horských hřbetů. K obecně známým patří druhy rodu Caryota s dvakrát zpeřenými listy, jejichž lístky mají tvar rybího ocasu. My jsme ji potkávali především ve vlhkých stržích v blízkosti horských toků, v těch nejmokřejších místech, které se v těchto horách vyskytují. Ostatní palmy patři spíše k drobným, podrostovým druhům, často horským. Krásným rodem je Licuala. Jsou to nádherné palmičky mlžných lesů, které jsme obdivovali i v okolí sedla Hon Giao. Teprve v roce 2011 byl popsán rod Lanonia, který je likualám blízce příbuzný a také podobný. K častějším palmám patří Areca a Pinanga. V kapitolce o palmách by neměla chybět hádanka - která rostlina nám doma dobře slouží a pěkně vypadá, zato $v$ přírodě se jí vyhýbáme, a pokud se jí nevyhneme, svorně ji všichni nenávidíme? Je to jednoduché ratan. Kdo neviděl (či nezažil), nepochopí, ale ratanová palma je dlouhatánská př́ǐsernost, děsivě trnitá na kmínku, řapících i listech. Listy jsou navíc zakončeny „bičem“ z prodloužené střední žíly, který vybíhá do vzdálenosti až 2 metry a má nazpět obrácené trny, ostré jako hadí zuby. Když zachytí za triko, lítají nitě, když za kưži, tak teče krev. Nejhorší noční můrou je ujet po vlhkém bahně na strmé stráni do ratanové houštiny - to i s tou kobrou by se snad člověk nějak domluvil, ale ratan je nekompromisní. Všichni nosíme v kapse nůžky, nejen na sběry, ale pokud se někdo z nás do ratanu chytí, musí se ven vystříhat. Tím větší úžas vyvolávají raglajští sběrači ratanu, kteří dokážou desetimetrový

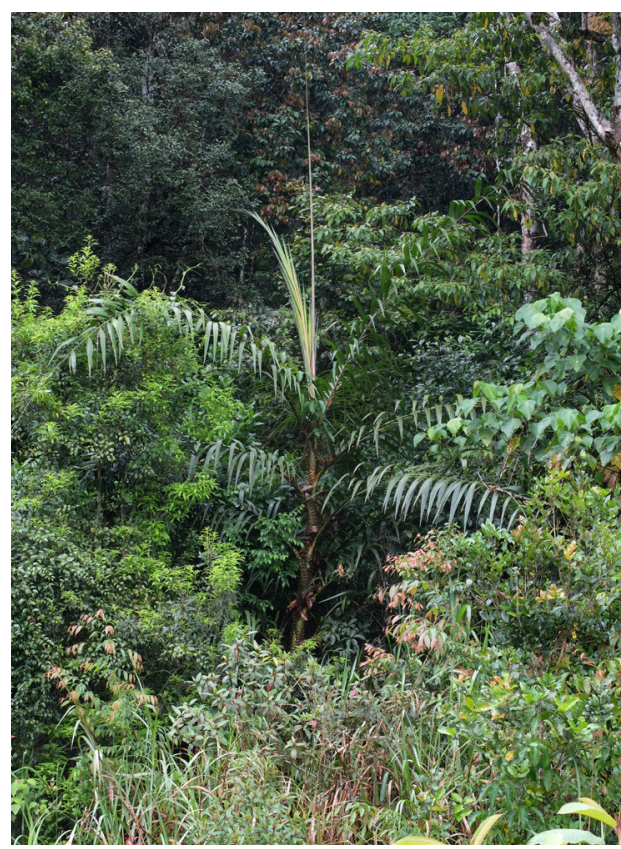

Obr. 21. Plectocomia elongata (Palmae) patři mezi ratany $\mathrm{k}$ těm větším.

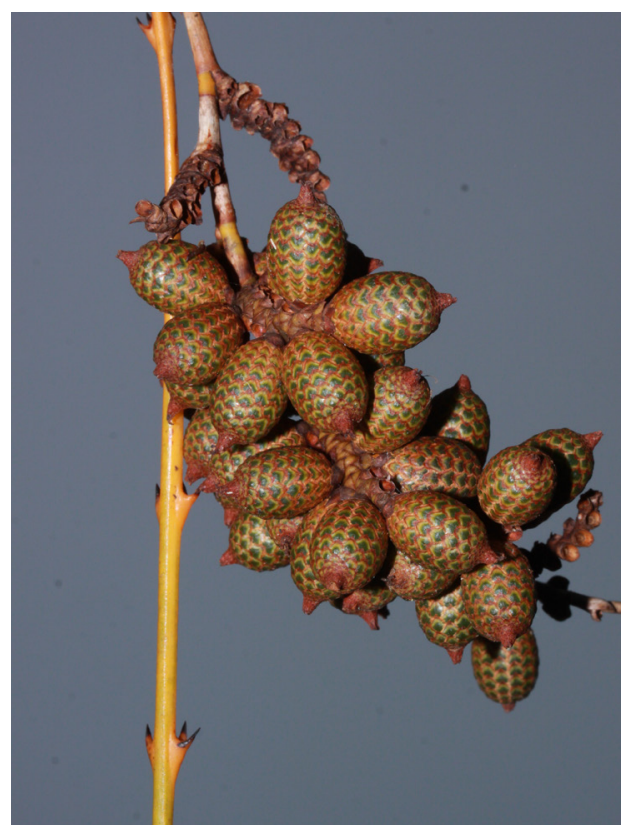

Obr. 22. Plody rodu Calamus (Palmae) mají na povrchu výrazné šupiny. 
kmínek ratanu podříznout, vytáhnout z porostu, oloupat kůru i s těmi ostny, kmínek naštípat na tenké proužky, stočit do balíků, vyvléct z lesa a dotáhnout domů.

Ratanových palem jsme potkávali vícero druhů z několika různých rodů. Velmi mohutná byla Plectocomia elongata. Je to ratan, který může být vysoký (nebo spíš dlouhý?) až ke třiceti metrům, rostlina nese složené, 3-5 m dlouhé listy a kmínek může být u báze až jako paže tlustý. Štíhlejší, alespoň ty vietnamské, jsou ratany z rodu Calamus. Co jim však chybí na mohutnosti, to tento rod dohání na druhovém bohatství. Patří sem asi 400 převážně asijských druhů, z nichž pár desítek roste i ve Vietnamu. Druhy, které jsme potkávali ve zdejších horských lesích, bývají vzrůstu středního až vysloveně drob-

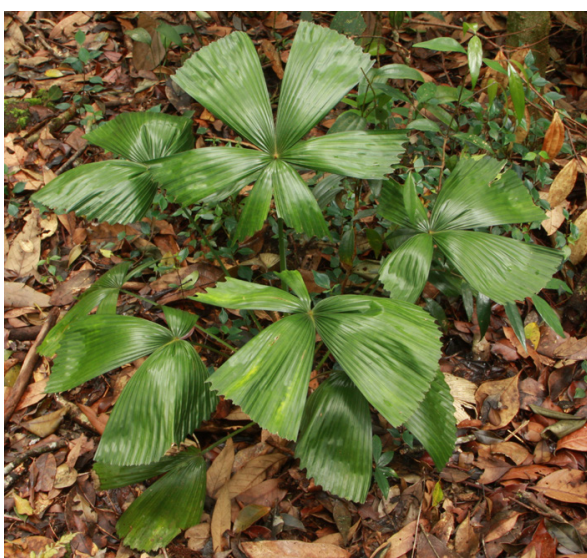

Obr. 23. Palmy rodu Licuala se vyznačují dlanitě zpeřenými listy. né, do tohoto rodu ale patří i rekordman s nejdelším přesně změřeným stonkem na světě, 240 m dlouhý Calamus manan z Indonésie. Posledním zástupcem této skupiny, se kterým jsme se ve zdejších lesích potkávali, byl elegantní rod Korthalsia vyznačující se kosníkovitými, často nesouměrnými lístky.

\section{Tropické jehličí}

Jehličnany v tropech se našim smrkům moc nepodobají. Jména Fokienia, Keteleeria, Dacrydium, Amentotaxus nebo Xanthocyparis znějí spíše jako zaklínadla z Harryho Pottera. Ale i z těch známých rodů ve Vietnamu roste několik druhů borovic a tis. I mezi borovicemi se tu vyskytuje skutečný unikát. Pinus krempfii je endemitem horských lesů pouze rezervace Hon Ba, Národního parku Bidoup - Nui Ba a několika vrcholů náhorní plošiny Lam Vien. V jejím areálu je známa necelá desítka populací s počtem maximálně 200 jedinců. V lesích kolem sedla Hon Giao se stále ještě vyskytuje několik desítek starých mohutných dospělých stromů. Tato statná borovice má velmi netypické jehlice semenáčků, ploché a široké, vyrůstající po dvou ve svazku. Roste v nadmořské výšce 1400-2000 metrů n. m., o její ekologii je toho známo velmi málo. Dosud zůstává neprobádáno její rozmnožování - v lese nalezneme relativně hojné semenáče, ale zcela chybí dorůstající generace. Nádherný jehličnan Fokienia hodginsii dorůstá výšky 35 m s průměrem kmene až 2 metry. Býval dominantní dřevinou stálezeleného horského lesa nad 1000 metrů nadmořské výšky. Dnes už roste jen v hodně nepřístupných nebo přísně střežených místech, nebot' jeho vysoce kvalitní dřevo je ceněné na výrobu nábytku. Žádaný je rovněž esenciální olej destilovaný především z kořenů. Tyto stromy jsou prastaré, rostou velice pomalu. Dendrochronologickou analýzou bylo zjištěno, že ti největší jedinci jsou staří přes 1300 let. Když Cyril s Metodějem přišli na Moravu, byly tyto stromy již stopadesátiletí jinoši v nejlepších letech. Nageia wallichiana, s kterou jsme se potkávali v těch nejvlhčích místech, patří k rodu s největšími i nejširšími jehlicemi na světě - u našeho druhu mohou být až $18 \mathrm{~cm}$ dlouhé a $5 \mathrm{~cm}$ široké, Nageia macrophylla dosahuje rozměrů až $30 \times 9 \mathrm{~cm}$. Nageia wallichiana je 10-30 m vysoký dvoudomý strom vyskytující se v deštných lesích pevninské jihovýchodní Asie v nadmořských výškách do $1000 \mathrm{~m}$. Býval běžný, ale jeho populace zdevastovala těžba kvalitního dřeva vhodného na výrobu hudebních nástrojů a nábytku. K méně ohroženým druhům patří Dacrydium elatum z podhorských a horských lesů jihovýchodní Asie a Tichomoří. Tento až 40 m vysoký dvoudomý strom je zajímavý svým olistěním - mladé jehlice jsou tenké, $2 \mathrm{~cm}$ dlouhé, rostou po celém obvodu větví a jsou zahnuté ke špičce výhonu; starší jehlice mají tvar trojúhelníkových šupin. Podobně je 

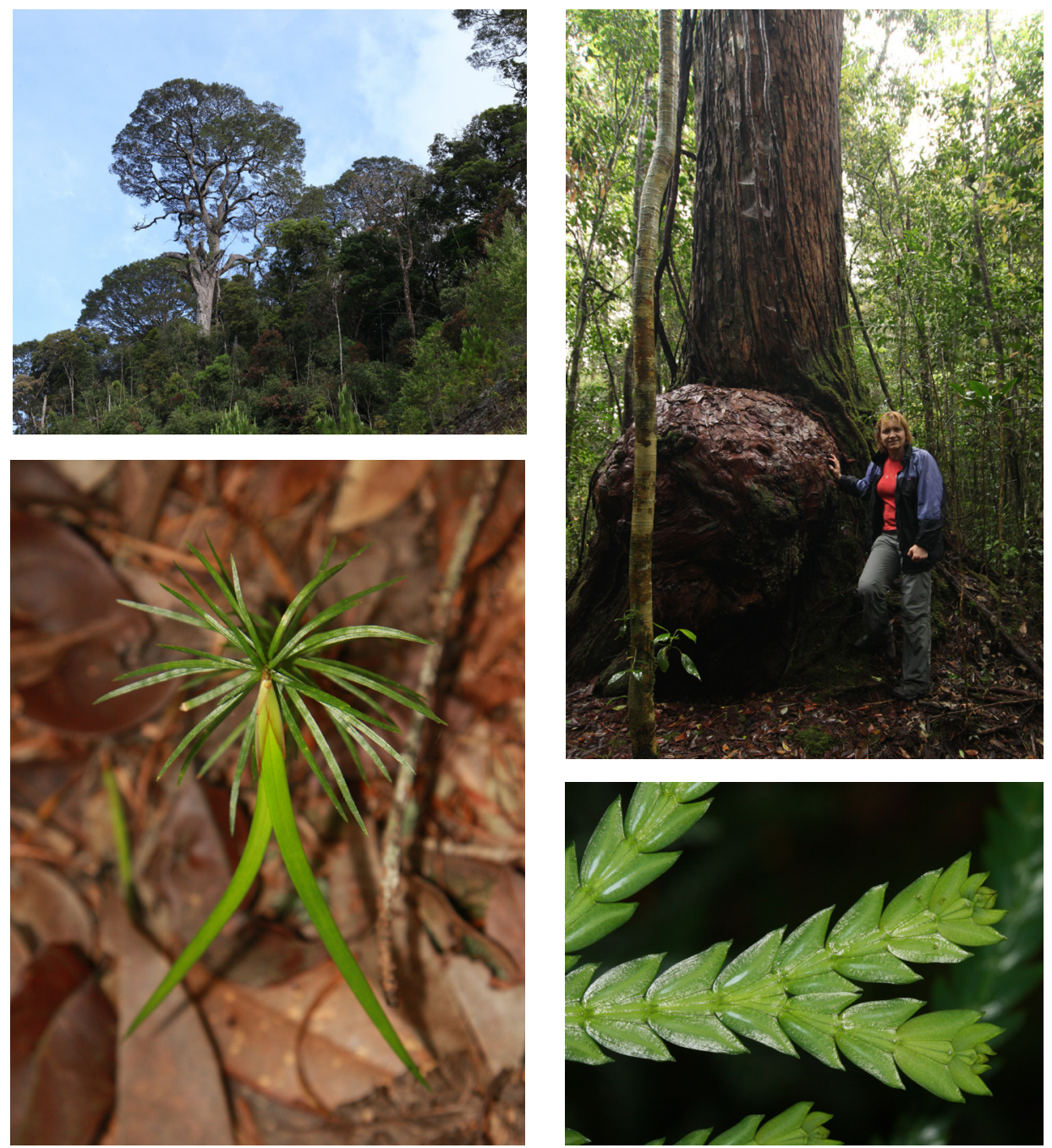

Obr. 24, 25. Pinus krempfii (Pinaceae) - děd a vnuk.

Obr. 26, 27. Fokienia hodginsii (Cupressaceae).

na tom Dacrycarpus imbricatus, který má stejný areál výskytu i dva typy jehlic - delší tenké na mladých výhoncích a šupinovité na starších větvích. Dnes již velice vzácná je Keteleeria evelyniana. Tento mohutný strom, jehlicemi nejvíce připomínající tis, se vztyčenými šišticemi, jejichž šupiny jsou vyhnuté do stran, jsme spatřili v jediném exempláři. Rostl uprostřed kávovníkové plantáže a přestože byl bohatě plodný, veškeré potomstvo pravidelně hynulo pod křovinořezy plantážníkovými...

\section{Zázvory, nejen do čaje}

Významnou složkou bylinného podrostu všude v jihovýchodní Asii tvoří zástupci čeledi zázvorovitých (Zingiberaceae). Čeled' zahrnuje asi 55 rodů a na dvě tisícovky druhů, a protože její zástupci jsou často obří, obtížně sbíratelní, dužnatí, s velmi tlustými květenstvími, z nichž vyrůstají velice delikátní květy, je jejich studium a zejména sběr dosti nesnadnou záležitostí. Proto se zároveň jedná o jednu z méně prozkoumaných čeledí, což spolu se skutečností, že 
jsou zároveň překrásné, úžasné, užitečné (tj. jedlé) a máme je rádi, je předurčuje k tomu býti zásadním objektem našeho zájmu. Mezery v jejich poznání jsou vskutku značné, v podstatě každá expedice do alespoň trochu neporušeného lesa kdekoli ve Vietnamu vede k objevu alespoň jednoho dosud nepopsaného nového druhu. Oblast Bidoupu začala být systematicky zkoumána až zhruba před dvaceti lety, kdy byla zpř́ístupněna novou silnicí přes sedlo Hon Giao. Za tu dobu bylo z oblasti popsáno několik desítek nových druhů cévnatých rostlin, mezi nimi i dva zázvory, Conamomum rubidum a Siliquamomum oreodoxa.

Zejména objev $S$. oreodoxa byl výrazným překvapením. Do té doby byl znám jediný druh, popsaný více jak před sto lety, rostoucí v horských lesích severního Vietnamu a přilehlé Č́ńn. Objev druhého druhu rodu o více jak 1000 km jižněji byl vskutku nečekaný. Rod Siliquamomum má v rámci zázvorů dosti výjimečné postavení. Představuje přechodný typ na pomezí dvou tribů, z nichž jeden je velice diversifikovaný a vyskytuje se v celém areálu čeledi, zato druhý obsahuje pouze několik rodů se značně disjunktním areálem: jižní Thajsko - Borneo - Papua-New Guinea. Taktéž morfologie je výjimečná: vedle zelenobílých květů jsou to především v celé čeledi unikátní plody, nejvíce připomínající tvarem i velikostí nezralé zelené fazole.

Během naší expedice se štěstí usmálo i na nás, a to hned dvakrát. Podařilo se nám objevit dva nové druhy z rodu
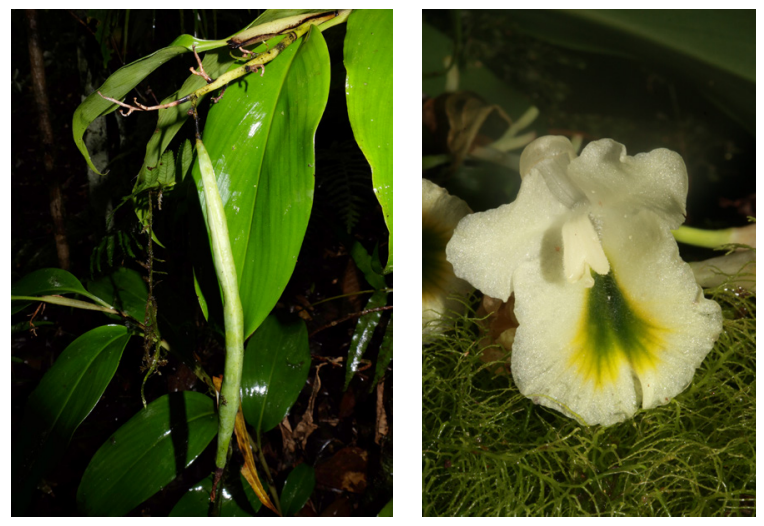

Obr. 28, 29. Siliquamomum oreodoxa (Zingiberaceae). Meistera, které jsme pojmenovali $M$. caudata (ocasatá - to podle dlouhého přívěsku, ve který vybíhá konec listů) a $M$. sudae (na památku našeho kamaráda a guru české botanické cytometrie Honzy Sudy). Oba druhy jsou doposud známy pouze z malé oblasti v blízkosti sedlo Hon Giao, M. sudae z několika mikrolokalit, $M$. caudata dokonce pouze z jediné. Je ale pravděpodobné, že se na podobných stanovištích horského stálezeleného lesa budou v oblasti vyskytovat i jinde.

Lesy nejenom zdejší oblasti bezpochyby ještě zdaleka nevydaly všechna svá tajemství. Proto kupte letenku, vezměte pohorky a vyražte. Odměnou za komáří štípance a bláto na zádech vám bude orchestr roztodivných tvarů i barev rostlin, někdy známých a povědomých, jindy zcela netušených.

\section{Poděkování}

Článek vznikl za finanční podpory Ministerstva kultury ČR (DKRVO 2019-2023/4.II.b, 00023272).

\section{Summary}

In 2007, the Prague Botanical Garden and the Botanical Department of the National Museum together organized an expedition to the Bidoup-Nui National Park in Vietnam. The park lies at the southern end of the Annamite mountain range, the southern-most tip of a ran- 
ges stretching down from the eastern edge of the Tibetan Plateau across all Indo-China. This ranges forms a migration corridors, which causes that we encounter here plants not only of a tropical character, but also from temperate zones, and is one of the primary reasons for IndoChina's biological diversity. Until the construction of a new road across the Hon Giao pass twenty years ago, the Bidoup massif was mostly inaccessible, and consequently, not well studied. Our expedition went to that area of that pass, and onto the actual massif of the highest mountain in the park, Mt. Bidoup.

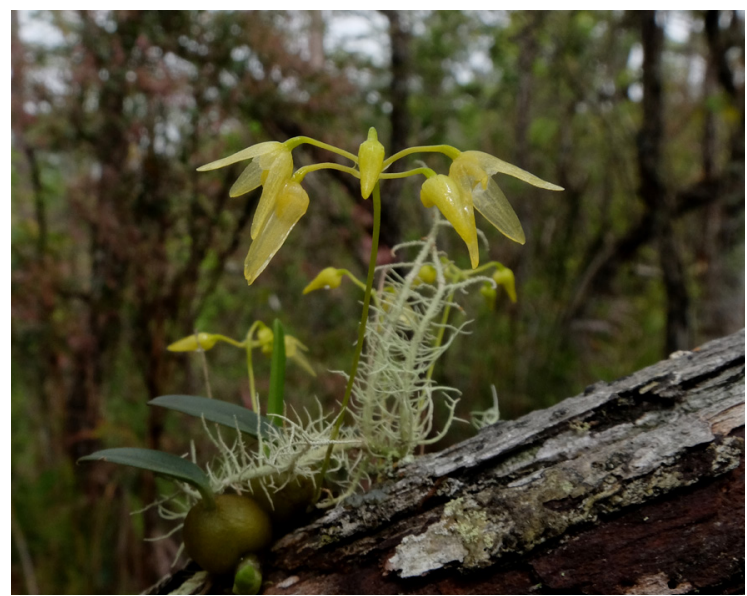

Obr. 30. Jeden z nesčetných druhů rodu Bulbophyllum (Orchidaceae).

Environmental conditions in this small area are quite diverse. The section of the mountain range containing the Hon Giao pass rises steeply from the surrounding coastal lowlands, presenting a serious barrier to air movement from the east, and so creates a significant climatic division. The crest and eastern slopes are extremely humid and well supplied with water pretty much all year around, while the territory a few kilometers further inland lies in the range's rain shadow, and so receives significantly less rainfall. Together with the elevation and edaphic conditions, this gives rise to several widely varying plant formations.

The crest and eastern slopes, with their steady supply of water, are covered in montane evergreen forest, typified by fewer layers than the lowland forests. However, it is still a thoroughly connected forest, with a markedly shaded interior. The forest comprises many species of tree, from tropical and sub-tropical types like Exbucklandia of the Hammamelidaceae family and Cammelia of the Theaceae family, through temperate types like Castanopsis, Quercus macrophylla oaks, Acer campbellii maples and Pinus krempfii pines. The most damp-loving species in the forest are found in deep cuts fed by local torrents, like Nageia wallichiana, Pentaphragma honbaense and the members of genus Argostemma.

Drier varieties of forest are found further from the crest, and are marked by periods of inadequate rainfall, together with the attendant vegetative quiescence. In the lower regions of the Bidoup massif we find pine forests of Pinus dalatensis, strikingly similar to central European pine forests. Both forests also host bracken ferns (Pteridium aquilinum).A different sort of forest grows in the summit regions of the crest and peaks, at elevations of around 1500 meters, where the effects of lesser rainfall are compounded by a specific edaphic condition a shallow soil layer. Forests here are noticeably shorter, sparser and contain an undergrowth of grasses and sedges. They also have numerous pioneer growths, which are likewise often found on disrupted substrates, like alongside new roads. Epiphytes are also abundant - ferns, orchids, members of heath family), mosses and lichens.

The area is distinctive for its numerous species of conifers. It contains the pine Pinus krempfii, endemic to the southern Annamites, 1300-year-old specimens of Fokienia hodginsii, prized for its hard and fragrant wood (and critically endangered for that same reason), Keteleeria evelyniana (also critically endangered), and others. Every year, new species are described from this national park. Even we found two new gingers in a shadow of these forests: Meistera sudae and Meistera caudata. 